International Journal of English Language and Literature Studies

$\operatorname{ISSN}(e): \quad 2306-0646$

$\operatorname{ISSN}(p): \quad 2306-9910$

DOI: $10.18488 /$ journal.23.2021.104.260.274

Vol. 10, No. 4, 260-274.

(C) 2021 AESS Publications. All Rights Reserved.

URL: www.aessweb.com

\title{
SAUDI EFL STUDENTS' PRODUCTION OF CONVENTIONAL EXPRESSIONS IN SECOND LANGUAGE PRAGMATICS
}

Afnan Almegren

\author{
Department of Applied Linguistics, College of Languages, Princess Nourah bint Abdulrahman University, \\ Riyadh, Saudi Arabia. \\ Email:amalmegren@pnu.edu.sa
}

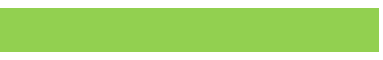

Article History

Received: 14 June 2021 Revised: 16 August 2021 Accepted: 20 September 2021 Published: 22 October 2021

\section{Keywords}

Contrastive pragmatics Conventional expressions Pragmatics

Production task

Saudi EFL learners.

\section{ABSTRACT}

This study compared and explored the differences and similarities in the production of conventional expressions between native English speakers and non-native English speakers represented by the Saudi EFL learners. It also examined the pragma-linguistic differences in the production of conventional expressions. Forty-seven native English speakers and forty-seven non-native English speakers participated in this study. The questionnaire consisted of nineteen scenarios representing different speech acts. Students were requested to reply to these scenarios as if they were real-life situations. The findings established that almost half of the comparisons between Saudi EFL learners and native English speakers presented similarities in the production of conventional expressions. However, there were some pragma-linguistic differences between the native English speakers and some of the Saudi EFL learners, such as misunderstandings due to the misuse of expected expressions, verbosity, the use of expressions that formal speakers considered rude, and transferred from their first language. These findings provide an empirical vision to the status of Saudi EFL learners conventional expressions. Future research could investigate conventional EFL expressions locally and globally.

Contribution/ Originality: This study is one of very few studies which have investigated language learning apart from language skills teaching. It explores sociolinguistic competence as an important aspect in foreign language fluency. It also sheds the light on the importance of pragmatic competence awareness acquaintance in enhancing the fluency levels.

\section{INTRODUCTION}

The language processing by native and non-native speakers has been of great interest to linguists. An important part of this process is the acquisition and comprehension of conventional expressions. Wujiabudula (2018) states that "Conventional expressions include strings of words (e.g., I am joking, I am sorry, no problem. etc.), which are predominantly applied in spoken language and often used by native speakers of English within the same speech community." Tateyama (2001) stressed the importance of conventional expressions for second language and interlanguage pragmatics. The conventional expressions play an important role in the acquisition of learners' second language. The comprehension of the second language is also affected by it. However, Schmitt and Carter (2004) argue that non-native speakers of English underuse these expressions. Even with high proficiency levels, EFL learners tend to face difficulties when using these expressions, as previous studies claim (e.g., Bardovi-Harlig and Vellenga (2012)). One of the reasons for language learners facing difficulties in learning conventional expressions is that it is not easy to link these expressions to their native language. Wray and Perkins (2000), on the 
other hand, consider conventional expressions as "survival phrases to achieve basic socio-economic interactional functions" for language learners with low proficiency levels (p. 23).

When investigating conventional expressions, sociolinguistic and pragmatic aspects arise. Wujiabudula (2018) points out that these expressions are important to learn as they help learners improve their everyday verbal communication. They also include society-sharing knowledge. The pragmatic success of a learner should reflect positively on their meaning production that is accepted by society (Wujiabudula, 2018). Considering the conventional expressions from sociolinguistic aspects, House (1996) says that "it is important to learn routines at any learning stage because they embody the societal knowledge that members of a given community share." House (1996) also adds that they are considered crucial in everyday verbal handling. Fairchild, Mathis, and Papafragou (2020) mention in their findings of a study on understanding the under-informativeness in the non-native and native speakers, which focused on pragmatics and social meaning, that non-native speech strongly affected the inferences of social-pragmatics. They add that this emphasizes theories concerning non-native comprehension and the effect of expectations. Their findings also confirm their hypothesis in which the identity of the speaker had an effect on how native learners treated utterances that were under-informative. They added that this would cause implications on the learning process.

This study aimed to explore the production of these expressions by Saudi students who study English as a foreign language (EFL), in relation to the similarities and differences as compared to native English speakers. It also examined the pragma-linguistic differences in the production of conventional expressions. This study is one of the few studies that examine language learning aside from teaching language skills. This study examines the importance of sociolinguistic competence in gaining foreign language fluency. It will also explore the importance of having learners acquainted with pragmatic competence to enhance learners' fluency levels.

\section{RESEARCH QUESTIONS}

This research attempted to answer the following questions:

1- What are the similarities between Saudi EFL students' and native English speakers' productions of conventional expressions?

2- Are there any pragma-linguistic features in the productions of conventional expressions by Saudi EFL learners that differ from those of native speakers?

\section{LITERATURE REVIEW}

\subsection{Conventional Expressions}

According to Bardovi-Harlig (2009) the term "conventional expressions" is beyond other terminologies as it focuses on social aspects. They are "a speech community's preference for a particular string and avoid the psycholinguistic claim regarding storage and retrieval.” (Bardovi-Harlig, 2009). A conventional expression is described as "a sequence, continuous or discontinuous, of words or other meaning elements, which is, or appears to be, prefabricated. They are stored and retrieved whole from memory at the time of use, rather than being subject to generation or analysis by the language grammar" (Wray \& Perkins, 2000). Coulmas (1981) states that these expressions are shared by members of a community.

The aim of sharing these expressions is to maintain interaction and facilitate communication and conversation (Coulmas, 1981; Kasper \& Schmidt, 1996; Wray, 1999). Conventional expressions have been classified into three functions that are considered main and interactional (Nattinger \& DeCarrico, 1992). The first classification is 'social interactions.' This comprises both the maintenance and the purpose of the conversation. The second is 'necessary topics.' This refers to the things that users of a language talk about the most, such as the weather and names. The third classification is 'discourse devices.' These devices include summarizers, exemplifiers, and temporal connectors. Other identifications of conventional expression functions are presented by Schmitt and Carter (2004). The first of 
the three functions that they presented is such conventional expressions that act as organizers of oral and written discourse. The next function was the maintenance of continuous conversation. The last function that they presented was to avoid confusion by making conversations more efficient.

After identifying the conventional expressions, presenting their different functions, and shedding light on their different aspects, it is important to note, as mentioned in the introductory section, that foreign language learners are viewed differently (Edmondson \& House, 1991). Bardovi-Harlig and Vellenga (2012) clarify this in their statement that language learners may not be able to link expressions to the context of the language they are learning and might instead link it to the target language function, thereby, not controlling their form and not being comfortable with using some of these expressions. This applies not only to low-and intermediate-level language learners but "even advanced learners who have learned a great many words and 'grammar rules' often fail to combine words the way native speakers do" (Boers and Lindstromberg (2009)(p. 1).

\subsection{Conventional Expressions and Second Language Pragmatics}

Conventional expressions are socially related. Pawley and Syder (1983) state that second language learners go through what they described as a 'puzzle' in which learners get confused when choosing a conventional native-like expression. They add that these learners must choose from what they refer to as range phrases that are grammatical and correct. This is difficult for them because, unlike native speakers, "they do not have easy access to standardized routines and, therefore, do not make use of them for meeting social impositions' (Edmondson \& House, 1991). Taguchi (2007) emphasizes that it is beneficial for language learners to understand the meaning of conventional expressions and be able to interpret direct or indirect statements depending on the context. Language learners tend to excel in the grammatical production of these expressions, but not pragmatically, as pragmatics do not mirror what native speakers produce, as Bardovi-Harlig (2009) concluded in his research on Asian participants.

\subsection{Related Previous Studies}

Conventional expressions and interlanguage pragmatics have attracted the interest of linguists and language researchers since the 1970s. One of the studies that examined the development of pragmatic comprehension was conducted by Taguchi (2008). It focused on cognition and language contact and its role in the development of pragmatic comprehension in the study-abroad context. It studied two issues. The first was to investigate whether there were gains in accurate and speedy second language comprehension of pragmatic meaning over time. The second was to explore whether there was a relationship between the ability to engage in cognitive processing and the amount of language contact in the environment of a second language. A total of 44 college students from an institution in the US participated in the study.

The participants underwent three different measurements three times each. This occurred over a four-month period. The first was a pragmatic listening test that aimed to measure whether the participant was able to comprehend the intentions of the speaker. The second was a lexical test that measured the participants' ability to make fast semantic judgments. The last measurement was a language contact survey that aimed to determine how much time the participants spent communicating in their second language outside of class. The researcher tested the pragmatic comprehension of the participants by analyzing their comprehension speed and accuracy. The findings revealed an improvement in the speed of comprehension but the accuracy of comprehension did not improve. There was also a correlation between comprehension speed and lexical speed. In addition, the results revealed that there was a correlation between the amount of reading and speaking outside of the class, and the speed of comprehension. None of the correlations included comprehension accuracy.

Bardovi-Harlig (2009) conducted another research study that investigated conventional expressions as a pragma linguistic resource. In her study, she investigated why second language learners are not able to have a higher level of use of conventional expressions that relate to pragma-linguistic competence. This was done by 
examining the connection between conventional expression production and recognition in second language pragmatics. A total of 122 English language learners from different backgrounds and 49 native English language speakers participated in this study. The study employed two different tasks, namely the recognition task and oral production task. The recognition task had 60 expressions and asked participants to respond to them by choosing an option that best reflected their level of familiarity with the subject. The choices were: I often, sometimes, or never hear this. The answers for the production task were delivered by a computer. Participants were presented with 32 scenarios and asked to give their responses orally. The findings of the study revealed that the causes of low usage of conventional expressions by second language learners may be related to the following: not being familiar with certain expressions, development level, knowledge of socio-pragmatics, and the overuse of expressions that are familiar to them. The researcher also found that it was necessary to recognize conventional expressions for production, however, this alone was not enough.

Another study that investigated conventional expressions was presented by Bardovi-Harlig and Vellenga (2012). It aimed to investigate the effects of instructions on particular conventional expressions that have certain pragmatic functions in oral production in the English language. A total of 36 university students participated in the study. They belonged to six intact and intensive English classes. A pre-test -instruction- post-test instrument was used to determine whether metapragmatic guidance noticing activities helped second language learners to produce more conventional expressions. It also aimed to investigate whether the findings could be generalized to include other conventional expressions. The participants were divided into two groups. Each group consisted of three classes. Two of the three groups received instructions on different expressions. The findings were significant in both groups that received instructions. One set of conventional expressions showed significance but not the other. This indicated that they needed clear instructions and transparent expressions. It also pointed out that it was constrained to the linguistic development level of the learner.

An investigation on the pragmatics and processing of conventional expressions was held by Edmonds (2014). In her study, the researcher focused on the multiword units. It was applied on 20 French natives, 20 long-stay and 20 short-stay Anglophone non-native speakers of French. Participants were administered a contextualized naturalness judgment task online. Findings of the study revealed that participants had similar judgment towards the conventional expressions given. It also revealed that the groups had significant differences from the matched conditions. These were related to grammar and not the conventional strings. Edmonds (2014) also states that natives' and non-natives' reaction time revealed that conventional expressions do have a mental correlate. She also states that it was the most consistent, as argued, with the pragmatic competence model related to conventional expression processing.

DeBoer (2015) investigated the production and recognition of second language learners' conventional expressions according to their proficiency, intensity of interaction, and length of stay. This study included three tasks. The first was the aural recognition task, which comprised 60 modified and conventional expressions. The second was the oral production task, which aimed to elicit conventional expressions, and was constructed to form 32 scenarios. The third was a questionnaire that aimed to measure the different factors that added to the intensity of environmental interaction in the second language. A total of 23 native English speakers and 52 second language learners participated in the study. The three one-way analysis of variance (ANOVA) tests revealed that second language proficiency had a clear effect on the production of conventional expressions. There was also a slightly significant effect on the recognition of conventional expressions. There was a clear influence of the intensity of the interaction on the production of conventional expressions in the initiating scenarios. The researcher also pointed out that the length of stay did not show significant effects on either conventional expression recognition or production.

Park (2016) conducted an interesting study on pragma-linguistic differences that Korean EFL learners had in producing conventional expressions. This study explored the differences between Korean EFL learners and native 
English speakers. This was done by applying an audio-visual production task. The findings of the study revealed that the results of Korean EFL learners were different from those of native speakers. This was apparent in almost half of the scenarios that involved conventional expression production. Park (2016) also mentioned that EFL learners tended to produce what was referred to as 'infelicitous utterances', from a pragma-linguistic perspective. The researcher also added that these expressions were acceptable from a grammatical perspective. EFL learners' production of conventional expressions was higher than that of native English speakers. The research findings also established that failure in communication may accrue in real-life situations. This was established in the research through expressions that were described as 'less target-like' in the scenarios that included thanks deflection and the display of gratitude.

The production of conventional expressions in L2 pragmatics under second language learners were also investigated in a study by Wujiabudula (2018). This study comprised a questionnaire that asked students to write down the oral responses that they would use in the 19 scenarios given to them. This production task had various speech acts for deflecting gratitude, declining invitations, agreements, accepting invitations, accepting requests, accepting offers, declining offers, requests, leave-taking, condolences, warning, gratitude expressions, apologies, etc. The participants of the study were second grade students in the Translation and Interpretation department at a private university. The findings of the study revealed that conventional expressions and second language pragmatics need to emphasize second language acquisition. The researcher also added that having second language learners interpret contexts given to them was a unique way to provide them the opportunity to develop accurate use of conventional expressions. It was also concluded that pragmatic knowledge of the second language was the key to improving communication, understanding, and accurate usage of everyday speech acts.

The current research will add to the body of literature concerning conventional expression production and second language pragmatics. It examines the aspects that Saudi EFL learners share with native English speakers when producing these expressions. It also presents features discovered during this research concerning the pragmalinguistic aspects where the two groups differ. This is the first study that focuses on Saudis and their production of conventional expressions from a pragmatic perspective of a second language. The findings will be of benefit to linguists, researchers, language instructors, and students. It will equip them with an empirical investigation of the status of conventional expressions among Saudi female EFL learners. It will shed lights on the needs of EFL learners based on the analyzed data. It will also assist foreign language curriculum developers by underlining the areas and materials that needs further consideration for language learners.

\section{METHODOLOGY}

\subsection{Participants}

This study comprised a total of 105 participants and included both native and non-native English speakers. Their ages ranged from 19 to 23 years. A total of 47 female students of Saudi English as a foreign language participated in this study. They were enrolled at Princess Nourah bint Abdulrahman University and studied at its Applied Linguistics Department. They demonstrated an upper-intermediate English proficiency. In addition, 47 native English speakers also participated in this study. Eleven questionnaires were discarded for being incomplete. This study was approved by the institutional review board at Princess Nourah bint Abdulrahman University. The participants were informed that their participation was voluntary, before data collection started. The researcher also confirmed that participation would be anonymized, and this was clearly stated in the information sheet provided to the students.

\subsection{Instruments}

A questionnaire consisting of 19 scenarios was used (Bardovi-Harlig, 2009) with slight modifications. These scenarios consisted of different speech acts such as accepting offers and requests, warning, declining an invitation, 
condolence, appreciation, etc. Students were requested to reply to these scenarios as if they were in real-life situations.

\subsection{Pilot Study}

A pilot study was conducted with 18 English major students to validate the feasibility of the study. The findings confirmed that the instrument was clear and easy to understand. This also confirmed that the questionnaire was feasible and reliable.

\subsection{Data Analysis}

In order to investigate the similarities in the production of conventional expressions between Saudi EFL students and native English speakers and to identify the pragma-linguistic features of production that differed from those of native speakers, 1786 responses were elicited. The responses were coded to specify the frequency of conventional expressions provided by participants in the situational dialogs. The expressions with the highest frequency were selected as the final accepted expressions.

\section{RESULTS}

The data is presented in two tables in this section. Each table includes the scenario, expressions that were produced, frequency, and the final accepted expression. Table 1 presents Saudi EFL learners' production of conventional expressions.

Table-1. Non-native speakers' (Saudi EFL learners) conventional expression production.

\begin{tabular}{|c|c|c|c|c|}
\hline No. & Scenario & Expression produced (non-native English speakers) & Frequency $(\%)$ & $\begin{array}{l}\text { Final accepted } \\
\text { expression }\end{array}$ \\
\hline 1 & $\begin{array}{l}\text { Dog was } \\
\text { hit by a } \\
\text { car }\end{array}$ & $\begin{array}{l}\text { I'm sorry to hear that. }(n=24) \\
\text { Oh, is he OK? }(n=14) \\
\text { I'm sorry for that. }(n=4) \\
\text { OMG, that's bad news. }(n=3) \\
\text { Ooh! that's so sad, did you take it to the veterinarian? } \\
(n=1) \\
\text { Do not worry he will be better soon. }(n=1)\end{array}$ & $\begin{array}{l}51.06 \% \\
29.78 \% \\
8.51 \% \\
6.38 \% \\
2.12 \% \\
2.12 \% \\
2.12 \%\end{array}$ & $\begin{array}{l}\text { I'm sorry to hear } \\
\text { that. }(n=24)\end{array}$ \\
\hline 2 & $\begin{array}{l}\text { Picking- } \\
\text { up a book } \\
\text { for } \\
\text { someone }\end{array}$ & $\begin{array}{l}\text { Thank you, I appreciate it }(n=14) \\
\text { Thank you so much }(n=10) \\
\text { That would be great, thank you. }(n=8) \\
\text { Thank you ( } n=6) \\
\text { That'd be so helpful, thank you. }(n=5) \\
\text { Really! Thank you. }(n=4)\end{array}$ & $\begin{array}{l}29.78 \% \\
21.27 \% \\
17.02 \% \\
12.76 \% \\
10.63 \% \\
8.51 \%\end{array}$ & $\begin{array}{l}\text { Thank you, I } \\
\text { appreciate } \\
(n=14)\end{array}$ \\
\hline 3 & $\begin{array}{l}\text { Thanking } \\
\text { for } \\
\text { coming }\end{array}$ & $\begin{array}{l}\text { Thank you for inviting me. }(n=17) \\
\text { You're welcome, it was fun. }(n=15) \\
\text { My pleasure. }(n=10) \\
\text { No problem. }(n=5)\end{array}$ & $\begin{array}{l}36.17 \% \\
31.91 \% \\
21.27 \% \\
10.63 \%\end{array}$ & $\begin{array}{lrr}\begin{array}{l}\text { Thank } \\
\text { inviting }\end{array} & \text { you } & \text { for } \\
(n=17) & \text { me. }\end{array}$ \\
\hline 4 & $\begin{array}{l}\text { Helping } \\
\text { someone }\end{array}$ & $\begin{array}{l}\text { Yes, please. }(n=35) \\
\text { Yes, thank you I'm looking for... }(n=5) \\
\text { No, thanks. }(n=4) \\
\text { I would appreciate that. }(n=2) \\
\text { Yes, I need help. }(n=1)\end{array}$ & $\begin{array}{l}74.46 \% \\
10.63 \% \\
8.51 \% \\
4.25 \% \\
2.12 \% \\
\end{array}$ & Yes, please $(\mathrm{n}=35)$ \\
\hline 5 & $\begin{array}{l}\text { Holding a } \\
\text { line for } \\
\text { someone }\end{array}$ & $\begin{array}{l}\text { Yeah, sure. }(n=28) \\
\text { OK, no problem. }(n=9) \\
\text { Yes, of course. }(n=7) \\
\text { Sure, don't be late please. }(n=2) \\
\text { Ok. }(n=1)\end{array}$ & $\begin{array}{l}59.57 \% \\
19.14 \% \\
36.17 \% \\
4.25 \% \\
2.12 \% \\
\end{array}$ & Yeah, sure. $(\mathrm{n}=28)$ \\
\hline
\end{tabular}




\begin{tabular}{|c|c|c|c|c|}
\hline 6 & $\begin{array}{l}\text { Have a } \\
\text { nice day }\end{array}$ & $\begin{array}{l}\text { Thanks, you too. }(n=25) \\
\text { You too. }(n=17) \\
\text { Thanks. }(n=2) \\
\text { And you also. }(n=1) \\
\text { Have a nice one too. }(n=1) \\
\text { That's so sweet, thank you. }(n=1)\end{array}$ & $\begin{array}{l}53.19 \% \\
36.17 \% \\
4.25 \% \\
2.12 \% \\
2.12 \% \\
2.12 \%\end{array}$ & $\begin{array}{l}\text { Thanks, you too. } \\
(\mathrm{n}=25)\end{array}$ \\
\hline 7 & $\begin{array}{l}5 \text { minutes } \\
\text { late for a } \\
\text { meeting }\end{array}$ & $\begin{array}{l}\text { Hello, I'm sorry for being late. }(n=44) \\
\text { Hello, I apologize for being late. }(n=2) \\
\text { Hello, I apologize for being late. How are you? }(n=1)\end{array}$ & $\begin{array}{l}93.61 \% \\
4.25 \% \\
2.12 \%\end{array}$ & $\begin{array}{l}\text { Hello, I'm } \begin{array}{r}\text { sorry } \\
\text { for being late. } \\
(n=44)\end{array}\end{array}$ \\
\hline 8 & $\begin{array}{l}\text { Bring } \\
\text { someone’s } \\
\text { book }\end{array}$ & $\begin{array}{l}\text { I'm sorry. I will bring it to you after class. }(n=29) \\
\text { Oh, I'm so sorry. I totally forgot to bring it. }(n=15) \\
\text { No, sorry I forget it at home I could bring it tomorrow. } \\
(n=2) \\
\text { Oh, I forgot it in my home, sorry. Let me help you with } \\
\text { your presentation. }(n=1)\end{array}$ & $\begin{array}{l}61.70 \% \\
31.91 \% \\
4.25 \% \\
2.12 \%\end{array}$ & $\begin{array}{l}\text { I'm sorry. I will } \\
\text { bring it to you } \\
\text { after class. }(\mathrm{n}=29)\end{array}$ \\
\hline 9 & $\begin{array}{l}\text { Thanking } \\
\text { for a ride }\end{array}$ & $\begin{array}{l}\text { Anytime. }(n=14) \\
\text { You're welcome. }(n=12) \\
\text { No need. }(n=11) \\
\text { No problem }(n=4) \\
\text { My pleasure. }(n=4) \\
\text { It's okay actually I live in the next building next to yours. } \\
(n=1) \\
\text { Wait we're neighbors! This is my home next to yours. } \\
(n=1)\end{array}$ & $\begin{array}{l}29.78 \% \\
25.53 \\
23.40 \% \\
8.51 \% \\
8.51 \% \\
2.12 \% \\
2.12 \%\end{array}$ & Anytime. $(n=14)$ \\
\hline 10 & $\begin{array}{l}\text { Coming } \\
\text { on } \\
\text { Friday's } \\
\text { party }\end{array}$ & $\begin{array}{l}\text { I'm sorry. I already have plans on Friday. }(n=32) \\
\text { Sure. Why not. }(n=9) \\
\text { Yes, of course I can. Thanks for invitation. }(n=2) \\
\text { I will definitely attend. }(n=2) \\
\text { OK. Thank you. }(n=1) \\
\text { Sure, I'll be there. }(n=1)\end{array}$ & $\begin{array}{l}68.08 \% \\
19.14 \% \\
4.25 \% \\
4.25 \% \\
2.12 \% \\
2.12 \%\end{array}$ & $\begin{array}{l}\text { I'm sorry. I } \\
\text { already have plans } \\
\text { on Friday. }(n=32)\end{array}$ \\
\hline 11 & $\begin{array}{l}\text { Studying } \\
\text { in a } \\
\text { library }\end{array}$ & $\begin{array}{l}\text { Yes. }(n=15) \\
\text { Yes, it is. }(n=11) \\
\text { Yes, absolutely. }(n=10) \\
\text { Yes, it's near my house. }(n=9) \\
\text { Yes, it is a very suitable place. }(n=1) \\
\text { Yes. It is the best; my house is near the library. }(n=1)\end{array}$ & $\begin{array}{l}31.91 \% \\
23.40 \% \\
21.27 \% \\
19.14 \% \\
2.12 \% \\
2.12 \% \\
\end{array}$ & Yes. $(n=15)$ \\
\hline 12 & $\begin{array}{l}\text { Do not } \\
\text { need help }\end{array}$ & $\begin{array}{l}\text { No, thank you. }(n=31) \\
\text { No, I'm good. }(n=6) \\
\text { No, thanks for asking. }(n=4) \\
\text { No, thanks I'm OK. }(n=4) \\
\text { Yes, please. }(n=1) \\
\text { No thank you so much but I'm only looking around. }(n=1)\end{array}$ & $\begin{array}{l}65.95 \% \\
12.76 \% \\
8.51 \% \\
8.51 \% \\
2.12 \% \\
2.12 \% \\
\end{array}$ & $\begin{array}{l}\text { No, thank you. } \\
(n=31)\end{array}$ \\
\hline 13 & $\begin{array}{l}\text { Talking } \\
\text { to your } \\
\text { teacher }\end{array}$ & $\begin{array}{l}\text { Thank you. I just have a quick question about... }(n=21) \\
\text { Can I talk to you? }(n=8) \\
\text { Good morning teacher, can I talk to you for a moment? } \\
(n=7) \\
\text { Hello miss, I need to talk to you. }(n=6) \\
\text { May I talk to you? }(n=3) \\
\text { Hi, I would like to talk to you about something. Are you } \\
\text { free? }(n=2)\end{array}$ & $\begin{array}{l}44.68 \% \\
17.02 \% \\
14.89 \% \\
12.76 \% \\
6.38 \% \\
4.25 \%\end{array}$ & $\begin{array}{l}\text { Thank you. I just } \\
\text { have a quick } \\
\text { question about... } \\
(\mathrm{n}=21)\end{array}$ \\
\hline 14 & $\begin{array}{l}\text { Replying } \\
\text { to the } \\
\text { invitation }\end{array}$ & $\begin{array}{l}\text { Yes, of course I will. }(n=25) \\
\text { Of course, I'll be there. }(n=9) \\
\text { Sure, thank you for the invitation. }(n=9) \\
\text { Sure, I would love to come. }(n=3) \\
\text { I'd love to but unfortunately, I can't. }(n=1)\end{array}$ & $\begin{array}{l}53.19 \% \\
19.14 \% \\
19.14 \% \\
6.38 \% \\
2.12 \%\end{array}$ & $\begin{array}{l}\text { Yes, of course I } \\
\text { will. }(n=25)\end{array}$ \\
\hline 15 & $\begin{array}{l}\text { Introduci } \\
\text { ng } \\
\text { someone }\end{array}$ & $\begin{array}{l}\text { Hi Sara, nice to meet you. }(n=30) \\
\text { Hi, my name is } \ldots(n=11) \\
\text { Hi, how are you? }(n=3) \\
\text { Pleased to meet you Sara! }(n=2) \\
\text { This is a great pleasure to meet you Sara. }(n=1)\end{array}$ & $\begin{array}{l}63.82 \% \\
23.40 \% \\
6.38 \% \\
4.25 \% \\
2.12 \%\end{array}$ & $\begin{array}{l}\text { Hi Sara, nice to } \\
\text { meet you. }(n=30)\end{array}$ \\
\hline
\end{tabular}




\begin{tabular}{|c|c|c|c|c|}
\hline 16 & $\begin{array}{l}\text { Death of } \\
\text { teacher's } \\
\text { father }\end{array}$ & $\begin{array}{l}\text { I'm so sorry for your loss. }(n=13) \\
\text { I am sorry to hear that. }(n=9) \\
\text { I'm sorry to hear this. May Allah have mercy on him. } \\
(n=9) \\
\text { I'm sorry. }(n=6) \\
\text { My condolences. }(n=5) \\
\text { May Allah bless his soul, are you okay? }(n=3) \\
\text { I was deeply saddened by the news of your father's } \\
\text { passing. My heartfelt condolences to you and your family. } \\
(n=1) \\
\text { I'm sorry for your loss. I will talk to you later. }(n=1)\end{array}$ & $\begin{array}{l}27.65 \% \\
19.14 \% \\
19.14 \% \\
12.76 \% \\
10.63 \% \\
6.38 \%\end{array}$ & $\begin{array}{l}\text { I'm so sorry for } \\
\text { your loss. }(n=13)\end{array}$ \\
\hline 17 & $\begin{array}{l}\text { Make-up } \\
\text { test }\end{array}$ & $\begin{array}{l}\text { Thank you so much, I promise that this will not happen } \\
\text { again. }(n=27) \\
\text { I won't. Thank you so much teacher. }(n=10) \\
\text { Ok, I will. Thank you so much. }(n=6) \\
\text { I will be sure that it never happens again. }(n=2) \\
\text { Sure, thank very much teacher. }(n=2)\end{array}$ & $\begin{array}{l}57.44 \% \\
21.27 \% \\
12.76 \% \\
4.25 \% \\
4.25 \%\end{array}$ & $\begin{array}{l}\text { Thank you so } \\
\text { much, I promise } \\
\text { that this will not } \\
\text { happen } \\
(\mathrm{n}=27)\end{array}$ \\
\hline 18 & $\begin{array}{l}\text { Offering a } \\
\text { ride }\end{array}$ & $\begin{array}{l}\text { Yes, please. }(n=28) \\
\text { Yes, thank you. }(n=11) \\
\text { Absolutely, thanks. }(n=4) \\
\text { Sure! Thanks, you're a life saver. }(n=2) \\
\text { No thank you I like walking under the rain. }(n=1) \\
\text { No, I will keep walking. }(n=1)\end{array}$ & $\begin{array}{l}59.57 \% \\
23.40 \% \\
8.51 \% \\
4.25 \% \\
2.12 \% \\
2.12 \% \\
\end{array}$ & Yes, please. $(n=28)$ \\
\hline 19 & $\begin{array}{l}\text { Need } \\
\text { more food }\end{array}$ & $\begin{array}{l}\text { No thank you, I'm full. }(n=34) \\
\text { I'm full. Thanks. }(n=6) \\
\text { No, thanks I'm stuffed. }(n=4) \\
\text { It's really delicious but I can't have more. }(n=3)\end{array}$ & $\begin{array}{l}72.34 \% \\
12.76 \% \\
8.51 \% \\
6.38 \%\end{array}$ & $\begin{array}{l}\text { No thank you, I'm } \\
\text { full. }(n=34)\end{array}$ \\
\hline
\end{tabular}

In the first scenario 24 participants, which amount to $51 \%$, used the expression "I'm sorry to hear that". The second scenario revealed that $29.78 \%$ used the expression "Thank you, I appreciate it" In scenario three, the most used expression was "Thank you for inviting me", with 17 participants having used this. In the fourth scenario, "yes, please" was used 35 times by Saudi EFL learners. For the fifth scenario, 28 of the participants replied with the expression "yeah, sure" as for the sixth scenario, the expression "Thanks, you too." was used 25 times. Scenario 7 displayed a notably high frequency usage of the expression "Hello, I'm sorry for being late.", which was used 44 times. The expression 'I'm sorry. I will bring it to you after class.' was used 29 times in scenario eight. In scenario nine the most used expression was "Anytime.", which was used by fourteen participants. "I'm sorry. I already have plans on Friday", was the most used expression in scenario 10 , with a frequency of $68.08 \%$. The results in scenario 11 show that most popular expression was "Yes." reaching a frequency of $31.91 \%$. As for scenario 12, the findings revealed that the highest-ranking expression was "No, thank you.", which was used a total of 31 times. The highest frequency in scenario 13 was $44.68 \%$ for the expression "Thank you. I just have a quick question about...". In scenario 14, the expression "Yes, of course I will." was used 25 times. The expression "Hi Sara, nice to meet you." was used 30 in scenario 15 and marked the highest frequency in this category. The findings made it apparent the most popular expression in scenario 16 was "I'm sorry for your loss", which was used 13 times. The most used expression among Saudi EFL learners in scenario 17 was "Thank you so much, I promise that this will not happen again.", which was used 27 times. In scenario 18, the expression "Yes, please” was used 28 times. Answers for the last scenario, scenario 19, show that the number one expression used was "No thank you, I'm full." with a frequency of $72 \%$.

Table 2 displays all expressions used by native English speakers. In scenario one, the expression "Oh, I'm sorry." was used 23 times, and was ranked as the most used expression. In scenario two, the expression used at the highest frequency was "Really! That would be great. Thank you so much." which was used 18 times. The most used expression in scenario three was "Thank you for inviting me." which was used 19 times. In scenario four, the expression " $Y e s, I ' m$ looking for a new shirt." was used 25 times by native English speakers. In scenario five, the most used expression was "Sure'." with a frequency of $74 \%$. 
Table-2. Native speakers' conventional expression production.

\begin{tabular}{|c|c|c|c|c|}
\hline No. & Scenario & Expression produced (native speakers) & Frequency (\%) & $\begin{array}{l}\text { Final accepted } \\
\text { expression }\end{array}$ \\
\hline 1 & $\begin{array}{l}\text { Dog was hit } \\
\text { by a car }\end{array}$ & $\begin{array}{l}\text { Oh, I'm sorry. }(n=23) \\
\text { Oh, no! is your dog OK? }(n=15) \\
\text { Oh my God, that's horrible! }(n=7) \\
\text { That's awful! }(n=1) \\
\text { Oh no! Is your pup OK? }(n=1)\end{array}$ & $\begin{array}{l}48.93 \% \\
31.91 \% \\
14.89 \% \\
2.12 \% \\
2.12 \% \\
\end{array}$ & $\begin{array}{l}\text { Oh, I'm sorry. } \\
(n=23)\end{array}$ \\
\hline 2 & $\begin{array}{l}\text { Picking-up } \\
\text { a book for } \\
\text { someone }\end{array}$ & $\begin{array}{l}\text { Really! That would be great, thank you so much. } \\
(n=18) \\
\text { Thank you so much. } n=(13) \\
\text { Really? That would be awesome! Thanks so much. } \\
(n=7) \\
\text { That would be so helpful. thank you so much! }(n=3) \\
\text { Alright, thanks. }(n=2) \\
\text { You're a lifesaver. }(n=2) \\
\text { Thanks! Where should I meet you to pick it up? }(n=1) \\
\text { Oh, can you? Are you sure it won't be out of the way } \\
\text { for you to do so? }(n=1)\end{array}$ & $\begin{array}{c}38.29 \% \\
27.65 \% \\
14.89 \% \\
6.38 \% \\
4.25 \% \\
4.25 \% \\
2.12 \% \\
2.12 \% \\
\end{array}$ & $\begin{array}{l}\text { Really! That } \\
\text { would be great, } \\
\text { thank you so } \\
\text { much. }(\mathrm{n}=18)\end{array}$ \\
\hline 3 & $\begin{array}{l}\text { Thanking } \\
\text { for coming }\end{array}$ & $\begin{array}{l}\text { Thank you for inviting me. }(n=19) \\
\text { Thanks for having me. }(n=11) \\
\text { Thank you for hosting. }(n=6) \\
\text { No problem! }(n=5) \\
\text { You're welcome! }(n=2) \\
\text { No worries, it was fun. }(n=2) \\
\text { My pleasure! Thanks a lot for the invite, I had a great } \\
\text { time. }(n=1) \\
\text { Of course, it was fun! }(n=1)\end{array}$ & $\begin{array}{l}40.42 \% \\
23.40 \% \\
12.76 \% \\
10.63 \% \\
4.25 \% \\
4.25 \% \\
\\
2.12 \% \\
2.12 \% \\
\end{array}$ & $\begin{array}{ll}\text { Thank you for } \\
\text { inviting } \\
(n=19)\end{array}$ \\
\hline 4 & $\begin{array}{l}\text { Helping } \\
\text { someone }\end{array}$ & $\begin{array}{l}\text { Yes, I'm looking for a new shirt. }(\mathrm{n}=25) \\
\text { Yes, please. }(\mathrm{n}=16) \\
\text { Yes, could you help me find a new shirt? }(\mathrm{n}=3) \\
\text { Nah, I'm good. }(\mathrm{n}=2) \\
\text { Just looking right now? thank you. }(\mathrm{n}=2) \\
\text { I'm ok for now, just browsing. }(\mathrm{n}=2) \\
\text { Yes, actually, do you know where I can find a new } \\
\text { shirt? }(\mathrm{n}=2)\end{array}$ & $\begin{array}{c}53.19 \% \\
34.04 \% \\
6.38 \% \\
4.25 \% \\
4.25 \% \\
4.25 \% \\
4.25 \% \\
\end{array}$ & $\begin{array}{l}\text { Yes, I'm looking } \\
\text { for a new shirt. } \\
(\mathrm{n}=25)\end{array}$ \\
\hline 5 & $\begin{array}{l}\text { Holding } a \\
\text { line for } \\
\text { someone }\end{array}$ & $\begin{array}{l}\text { Sure. }(n=35) \\
\text { Of course. }(n=5) \\
\text { Okay... how long are you gonna be? }(n=3) \\
\text { No problem, just hurry back. }(n=2) \\
\text { As long as we're just standing here sure. }(n=1) \\
\text { Nope. }(n=1)\end{array}$ & $\begin{array}{c}74.46 \% \\
10.63 \% \\
6.38 \% \\
4.25 \% \\
2.12 \% \\
2.12 \%\end{array}$ & Sure. $(n=35)$ \\
\hline 6 & $\begin{array}{l}\text { Have a nice } \\
\text { day }\end{array}$ & $\begin{array}{l}\text { Thanks. You too. }(n=25) \\
\text { You too. }(n=21) \\
\text { You as well. }(n=1)\end{array}$ & $\begin{array}{l}53.19 \% \\
44.68 \% \\
2.12 \% \\
\end{array}$ & $\begin{array}{l}\text { Thanks. You } \\
\text { too. }(\mathrm{n}=25)\end{array}$ \\
\hline 7 & $\begin{array}{l}5 \text { minutes } \\
\text { late for a } \\
\text { meeting }\end{array}$ & $\begin{array}{l}\text { Sorry I'm late. }(n=33) \\
\text { Thanks, sorry for being late. }(n=7) \\
\text { Sorry I'm a little late. }(n=3) \\
\text { Hi! I'm so sorry I'm a bit late. Do you still have time } \\
\text { to meet? }(n=3) \\
\text { Sorry for the delay! }(n=1)\end{array}$ & $\begin{array}{l}70.21 \% \\
14.89 \% \\
6.38 \% \\
\\
6.38 \% \\
2.12 \% \\
\end{array}$ & $\begin{array}{l}\text { Sorry I'm late. } \\
(n=33)\end{array}$ \\
\hline 8 & $\begin{array}{l}\text { Bring } \\
\text { someone’s } \\
\text { book }\end{array}$ & $\begin{array}{l}\text { I'm sorry, I forgot it at home. }(n=24) \\
\text { I'm so sorry. I forgot it, but I'll get it to you today. } \\
(n=10) \\
\text { I'm so sorry I forgot. I'll bring it tomorrow. }(n=8) \\
\text { I'm so sorry I completely forgot! I will get it to you } \\
\text { after school today. }(n=3) \\
\text { Oh no! I forgot it, sorry. Let me go home and get it. } \\
(n=1) \\
\text { I am so sorry, I left it at home. Is there any way for } \\
\text { me to get it to you later today or early tomorrow? } \\
(n=1)\end{array}$ & $\begin{array}{l}51.06 \% \\
21.27 \% \\
17.02 \% \\
6.38 \% \\
2.12 \% \\
2.12 \%\end{array}$ & \\
\hline
\end{tabular}




\begin{tabular}{|c|c|c|c|c|}
\hline 9 & $\begin{array}{l}\text { Thanking } \\
\text { for a ride }\end{array}$ & $\begin{array}{l}\text { No problem. }(n=32) \\
\text { Anytime. }(n=9) \\
\text { No worries. }(n=2) \\
\text { You're welcome. }(n=2) \\
\text { Yeah. Have a good night! }(n=1) \\
\text { No problem, see you tomorrow. }(n=1)\end{array}$ & $\begin{array}{c}68.08 \% \\
19.14 \% \\
4.25 \% \\
4.25 \% \\
2.12 \% \\
2.12 \%\end{array}$ & $\begin{array}{l}\text { No } \\
(\mathrm{n}=32)\end{array}$ problem. \\
\hline 10 & $\begin{array}{l}\text { Coming on } \\
\text { Friday's } \\
\text { party }\end{array}$ & $\begin{array}{l}\text { I'm sorry, I already have plans. }(n=26) \\
\text { I don't think I'll be able to make it. }(n=7) \\
\text { Yes, I can, thank you for the invitation. }(n=5) \\
\text { Yes of course. }(n=3) \\
\text { I'm busy that night, but thanks for the offer. }(n=3) \\
\text { I'm not sure; I'll have to check my schedule. I'll be } \\
\text { sure to let you know tomorrow though. }(n=2) \\
\text { Thank you, but I'm not free then. }(n=1)\end{array}$ & $\begin{array}{l}55.31 \% \\
14.89 \% \\
10.63 \% \\
6.38 \% \\
6.38 \% \\
4.25 \% \\
2.12 \%\end{array}$ & $\begin{array}{l}\text { I'm sorry, I } \\
\text { already have } \\
\text { plans. }(\mathrm{n}=26)\end{array}$ \\
\hline 11 & $\begin{array}{l}\text { Studying in } \\
\text { a library }\end{array}$ & $\begin{array}{l}\text { Yep/Yes. }(n=26) \\
\text { Sounds good. }(n=7) \\
\text { Works for me. }(n=10) \\
\text { Good with me. }(n=1) \\
\text { Perfect! It's not far for me. }(n=1) \\
\text { Yeah, I live super close to there! }(n=1) \\
\text { Yeah cool that's good for me. }(n=1)\end{array}$ & $\begin{array}{l}55.31 \% \\
14.89 \% \\
21.27 \% \\
2.12 \% \\
2.12 \% \\
2.12 \% \\
2.12 \%\end{array}$ & $\begin{array}{l}\text { Yep/Yes. } \\
(\mathrm{n}=26)\end{array}$ \\
\hline 12 & $\begin{array}{l}\text { Do not } \\
\text { need help }\end{array}$ & $\begin{array}{l}\text { No, thanks. }(n=23) \\
\text { No thanks I'm good. }(n=7) \\
\text { No, thank you, I'm just browsing. }(n=4) \\
\text { No thanks, I'm just looking. }(n=5) \\
\text { I'm okay. }(n=3) \\
\text { Thank you, but I'm ok. }(n=2) \\
\text { I'm alright thank you. }(n=1) \\
\text { I'm fine, thank you. }(n=1) \\
\text { Nope. I'm good. }(n=1)\end{array}$ & $\begin{array}{c}48.93 \% \\
14.89 \% \\
8.51 \% \\
10.63 \% \\
6.38 \% \\
4.25 \% \\
2.12 \% \\
2.12 \% \\
2.12 \% \\
\end{array}$ & $\begin{array}{l}\text { No, } \\
(\mathrm{n}=23)\end{array} \quad$ thanks. \\
\hline 13 & $\begin{array}{l}\text { Talking to } \\
\text { your } \\
\text { teacher }\end{array}$ & $\begin{array}{l}\text { Hi, do you have a moment? }(n=16) \\
\text { Hey. I've got questions about... }(n=9) \\
\text { hey, do you have a second? }(n=7) \\
\text { Excuse me, I just wanted to ask about... }(n=5) \\
\text { I need to ask you about... }(n=4) \\
\text { Hi are you free right now? }(n=2) \\
\text { Hi, is now a good time? }(n=2) \\
\text { Hi, I was hoping to speak with you for a few minutes. } \\
\text { Is now a good time? }(n=1) \\
\text { Do you have some time to meet with me? }(n=1)\end{array}$ & $\begin{array}{c}34.04 \% \\
19.14 \% \\
14.89 \% \\
10.63 \% \\
8.51 \% \\
4.25 \% \\
4.25 \% \\
2.12 \% \\
2.12 \% \\
\end{array}$ & $\begin{array}{l}\mathrm{Hi} \text {, do you have } \\
\text { a moment? } \\
\mathrm{n}=16)\end{array}$ \\
\hline 14 & $\begin{array}{l}\text { Replying to } \\
\text { the } \\
\text { invitation }\end{array}$ & $\begin{array}{l}\text { Yes, I'll be there. }(n=16) \\
\text { Of course. }(n=6) \\
\text { Yeah, sure! }(n=5) \\
\text { Absolutely! I am looking forward to it. }(n=4) \\
\text { Yes! I'll see you there. }(n=4) \\
\text { Sounds great! I'll definitely be there! }(n=3) \\
\text { Definitely! }(n=3) \\
\text { Sure! Sounds great. }(n=3) \\
\text { Definitely! Looking forward to it. }(n=2) \\
\text { Yes, I can come. }(n=1)\end{array}$ & $\begin{array}{c}34.04 \% \\
12.76 \% \\
10.63 \% \\
8.51 \% \\
8.51 \% \\
6.38 \% \\
6.38 \% \\
6.38 \% \\
4.25 \% \\
2.12 \%\end{array}$ & $\begin{array}{l}\text { Yes, } \quad \text { I'll be } \\
\text { there. }(n=16)\end{array}$ \\
\hline 15 & $\begin{array}{l}\text { Introducing } \\
\text { someone }\end{array}$ & $\begin{array}{l}\text { Hi Sara, nice to meet you. }(\mathrm{n}=27) \\
\text { Hi, I'm [name]. }(\mathrm{n}=16) \\
\text { Hi. }(\mathrm{n}=3) \\
\text { Hi, pleased to meet you. }(\mathrm{n}=1)\end{array}$ & $\begin{array}{c}57.44 \% \\
34.04 \% \\
6.38 \% \\
2.12 \%\end{array}$ & $\begin{array}{l}\text { Hi Sara, nice to } \\
\text { meet } \\
(n=27)\end{array}$ \\
\hline 16 & $\begin{array}{l}\text { Death of } \\
\text { teacher's } \\
\text { father }\end{array}$ & $\begin{array}{l}\text { I'm so sorry to hear that. }(n=17) \\
\text { I'm so sorry. }(n=16) \\
\text { I'm so sorry for your loss. }(n=13) \\
\text { That's terrible. I'm sorry. }(n=1)\end{array}$ & $\begin{array}{c}36.17 \% \\
34.04 \% \\
27.65 \% \\
2.12 \% \\
\end{array}$ & $\begin{array}{lr}\text { I'm so } & \text { sorry to } \\
\text { hear } & \text { that. } \\
(n=17) & \end{array}$ \\
\hline 17 & $\begin{array}{l}\text { Make-up } \\
\text { test }\end{array}$ & $\begin{array}{l}\text { Thanks so much! }(n=26) \\
\text { Thank you. }(n=12) \\
\text { I won't. }(n=6) \\
\text { Yes, I understand. Thank you very much for } \\
\text { accommodating me this time. }(n=1)\end{array}$ & $\begin{array}{l}55.31 \% \\
25.53 \% \\
12.76 \% \\
2.12 \%\end{array}$ & $\begin{array}{l}\text { Thanks } \\
\text { much! }(\mathrm{n}=26)\end{array}$ \\
\hline
\end{tabular}




\begin{tabular}{|c|c|c|c|c|}
\hline & & $\begin{array}{l}\text { I won't. Thank you }(n=1) \\
\text { Of course, thank you. }(n=1)\end{array}$ & $\begin{array}{l}2.12 \% \\
2.12 \% \\
\end{array}$ & \\
\hline 18 & $\begin{array}{l}\text { Offering a } \\
\text { ride }\end{array}$ & $\begin{array}{l}\text { Yes please! }(n=23) \\
\text { Yes. }(n=7) \\
\text { Thank you! }(n=6) \\
\text { That would be great, thank you! }(n=4) \\
\text { Yeah, are you sure? Thanks. }(n=3) \\
\text { Really? If you don't mind. }(n=1) \\
\text { Is that alright? ( } n=1) \\
\text { Would you? I'd really appreciate it. }(n=1) \\
\text { No thanks, I'm good. }(n=1)\end{array}$ & $\begin{array}{l}48.93 \% \\
14.89 \% \\
12.76 \% \\
8.51 \% \\
6.38 \% \\
2.12 \% \\
2.12 \% \\
2.12 \% \\
2.12 \% \\
\end{array}$ & $\begin{array}{l}\text { Yes } \\
(\mathrm{n}=23)\end{array}$ \\
\hline 19 & $\begin{array}{l}\text { Need more } \\
\text { food }\end{array}$ & $\begin{array}{l}\text { No thanks, I'm stuffed! }(n=19) \\
\text { No thanks I'm full. }(n=12) \\
\text { I can't, I'm full. }(n=7) \\
\text { No thank you, I'm super full. }(n=2) \\
\text { I'm stuffed thanks but it was delicious. }(n=2) \\
\text { This was incredible, but I'm so full. }(n=1) \\
\text { I'm stuffed thanks but it was delicious. }(n=1) \\
\text { Just a tiny little bit please. }(n=1) \\
\text { Ah, no thanks, I think I've had enough for now." } \\
\text { (n=1) } \\
\text { Ahhh, no thank you. I'm so stuffed, everything was so } \\
\text { good. }(n=1)\end{array}$ & $\begin{array}{l}40.42 \% \\
25.53 \% \\
14.89 \% \\
4.25 \% \\
4.25 \% \\
2.12 \% \\
2.12 \% \\
2.12 \% \\
2.12 \% \\
2.12 \%\end{array}$ & $\begin{array}{l}\text { No thanks, I'm } \\
\text { stuffed! }(n=19)\end{array}$ \\
\hline
\end{tabular}

The expression "Thanks. You too." was used 25 times in scenario six. In scenario seven, the expression "Sorry I'm late." was used 33 times. Scenario eight revealed that the most popular expression was "I'm sorry, I forgot it at home." at a frequency of $24 \%$. The results established that the most used expression in scenario nine was "No problem.", which was used 32 times. "I'm sorry, I already have plans." ranked the highest used expression, with a frequency of $55.31 \%$ in scenario 10 . The results also show that the expression " $Y e p / Y_{e s}$." was the most frequently used one in scenario 11, in which it was used 26 times. In scenario 12, the top expression used by participants was "No, thanks." with a frequency of 48\%. The expression "Hi, do you have a moment?' was used 16 times in scenario 13. In scenario 14, the expression "Yes, I'll be there" had the highest frequency at $34.04 \%$. In scenario 15 the expression "Hi Sara, nice to meet you." was the most frequently used expression and was used 27 times. In scenario 16, the most used expression was "I'm so sorry to hear that." with a frequency of $36 \%$. In scenario 17 , the most frequently used option was "Thanks so much!" with a frequency of 55.31\%. The expression "Yes please" was used 23 times and ranked the highest frequency in scenario 18. In the final scenario, scenario 19, the expression "No thanks, I'm stuffed!" was used 19 times, and was ranked the most used expression.

\section{DISCUSSION}

The findings of this research are presented as answers to the research questions. The first research question aimed to find similarities in the production of conventional expressions between Saudi EFL students and native English speakers.

The results of the study showed that the expressions used by Saudi EFL learners were 47.36\% akin to those used by the native English speakers, which is almost half of the participant pool. The data revealed similarities in scenarios, 3,5,6,10, 11, 12, 14, 15, and 18 .

The first similarity was observed in scenario three. Both the Saudi EFL learners and native English speakers had the same highest-ranking expression, which was "Thank you for inviting me.". This expression was used 17 times by Saudi EFL learners and 19 times by native English speakers, in their attempts to deflect thanks. These findings show the high pragmatic competence of conventional expressions in deflecting thanks where the findings of Wujiabudula (2018) revealed the opposite, where participants faced difficulties in recognizing the scenario of deflecting thanks. The second similarity appeared in the fifth scenario while replying to someone's request, where the expression "Yeah, sure" was used by the Saudi EFL group 28 times and the expression "Sure" was used by the 
native English speakers 35 times. This contradicts Gu (2011) findings, which emphasized that making a request was one of the challenging speech acts to be acquired (p. 105).

There were also apparent similarities in the sixth scenario, which stimulated expressions. The expression that ranked the highest in both groups was "Thanks, you too.". The frequency in both groups was 53\%. Geeslin and Gudmestad (2010) concluded that high English proficiency learners tend to use the same forms as native speakers. This idea was also clear in this study, as both groups used the same expression with the exact frequency. Scenario 10 shared similar findings for Saudi EFL learners and native English speakers in the expression used for the Strategy of Apology. The expression "I'm sorry. I already have plans on Friday." As used by the Saudi EFL learners and the expression "I'm sorry, I already have plans." by the native English speakers were both in the highest ranking, with a frequency of $68.08 \%$ for the first and $55.31 \%$ for the second. Cedar (2017) asserts that, as the level of English proficiency increases, learners' apology performance increases, which confirms the results of this study, where the participants represented upper intermediate English proficiency. The eleventh scenario also accepted the offer strategy expression used by both groups. The expression "Yes" was used by Saudi EFL learners 15 times and "Yep/Yes" was used by native speakers of English 26 times. Scenario 12 was the eliciting strategy of the declining officer. Similarities were apparent in the highest-ranking expression in both groups. The Saudi EFL learners used the expression "No, thank you" 31 times and the Native English speakers used the expression "No, thanks." 23 times.

Ellis (2008) asserts that refusing demands a high level of non-native pragmatic competence. This is also stressed by Félix-Brasdefer (2003) who emphasized that having a great linguistic proficiency level does not necessitate that participants are socio-culturally knowledgeable in the target language. Al-Kahtani (2005) also declares that "saying no is difficult for non-native speakers" and that it requires special skills such as knowledge of the cultural linguistic values of the target language. Accepting an invitation was implemented in scenario 14. The expression levels produced by both groups were similar. This was also pointed by Fairchild et al. (2020) in which they say that “...under-informativeness is more likely to be attributed to inability (rather than unwillingness) to say more in non-native as compared to native speakers." (p.1). Saudi EFL learners used the expression "Yes, of course I will." 25 times and was ranked the highest expression used by them. The expression "Yes, I'll be there." was used 16 times by native English speakers. This contradicts the results of Garcia (2004) study. Her study showed that although proficiency had a great impact on pragmatic comprehension, participants faced difficulties with offers. Looking at it from an implication for learning point, Fairchild et al. (2020) point that this asymmetry reveals that teachers who are under-informative have more chances in getting another chance when the language they are speaking is not their native language. They explain that it is because under informativeness used by them has less chances of being intentional. The highest-ranking Introductory Strategy expression used by both groups was " $H i$ Sara, nice to meet you." which was used 30 times. A similar expression was used by the Native English speakers, "Hi Sara, nice to meet you'.". It was used 27 times. This high frequency is equivalent to the results of Wujiabudula (2018) where $79.16 \%$ of the non-native English speakers replied with "nice to meet you" This confirms that the introduction strategy can be mastered at a wide range of English proficiency levels and pragmatic competence levels. Another similarity was also observed in scenario 18, which was based on the Offer Strategy. The shared expression for both groups was "Yes please!' which was used 23 times and "Yes, please" which was used 28 times. This contradicts the results of Garcia (2004) study mentioned above.

The second research question aimed to investigate whether there were any pragma-linguistic features of Saudi EFL learners' production of conventional expressions that differed from native speakers. Data analysis presented an interesting conclusion, that the production of 'conventional expressions' by Saudi EFL learners is very similar to native English speakers. Although there were slight differences in the frequency, the groups mostly produced the 
same expressions. One reason for this was the English proficiency level of the participants. They represented the upper intermediate English proficiency level, which is considered a good English level. Another reason is the wide acceptance of the world the Saudi government developed and the openness it developed towards it. Yusuf and Huda (2016) states that the new changes happening in Saudi Arabia are the biggest economic shake up that the country is going through since the year of 1932 where the Kingdom of Saudi Arabia was found. Just a couple of years ago, the Saudi government opened tourism to the rest of the world and approved the opening of cinemas in the Kingdom. Therefore, there was an easy access to English speakers and films. Whether at cinemas or at home through streaming platforms such as Netflix and so forth, access to native expressions had been easier than before. In fact, it is more practical than to learn them from textbooks. What Saudis are going through in learning English language specifically is considered an essential in coping with the spreading of technology around the world (Mukhallafi, 2019). This similarity in the production of conventional expressions used by native English speakers and non-native English speakers contradicts a previous study based on investigation of Korean EFL learners (Park, 2016), which emphasized that even high-proficiency students did not attain native-like use of conventional expressions. Similarly, Boers and Lindstromberg (2009), too, stressed that even highly proficient English learners "fail to combine words the way native speakers do". On the other hand, it is worth noting that some learners produced expressions that did not have the efficient pragma-linguistic means to be understood by the speaker. Grice (1975) has ruled out four maxims of conversation to be understood by the speaker: quantity that gives sufficient information but not too much, quality which is based on telling the truth, relevance that is relevant to the topic, and manner which means to be clear and intelligible. Thus, these participants had few pragma-linguistic deviations, and some violated the quantity maxim by for overly wordiness. Some did not understand what expression they should use such as is seen in scenario 12 while replying to the salesperson where participants were supposed to decline the offer. One person replied with: "Yes, please." A similar misunderstanding occurred in scenario 10, which was about attending the party on Friday. 19.04\% of the participants replied with "Sure. Why not?", where they were supposed to decline the offer. Another Saudi participant violated the maxim of quantity in scenario 12, which led to verbosity such as "No thank you so much but I'm only looking around." Situation 16 also showed wordiness "I was deeply saddened by the news of your father's passing. My heartfelt condolences to you and your family." This was not used by native speakers. The issue of verbosity is common in second language learners and has been stressed in recent and old research (Chen, 2006; Edmondson \& House, 1991; Park, 2016). Another expression that was used in scenario 13 for the situation of talking to your teacher and being considered rude, “Can I talk to you?”. This expression was used by $17.02 \%$ of the participants. What is also interesting in this scenario is that most of the expressions used by the Saudis were somewhat different from those used by native speakers. Scenario 16 also had some pragma-linguistic deviation from the native English speakers, where it represented first language transfer from their native language, which is Arabic. 25.52\% of the participants replied to death of teachers' father with "May Allah bless his soul, are you okay?" and "I'm sorry to hear this. May Allah have mercy on him." which shows the language transfer from Arabic to English. Another response that could be considered culturally inappropriate is the expression used in scenario 18 as a reply to someone offering a ride in the rain where one participant replied with: "No, I will keep walking." This is considered rude.

\section{CONCLUSION}

To conclude, the results of this study have revealed similarities in the production of conventional expressions between Saudi EFL learners and native English speakers. The Saudi usage of expressions was about 47.36\% similar to that of native English speakers. It is also worth noting that Saudi learners used the same expressions as the natives in most of the remaining scenarios, but the difference was in their frequency number being lower than that of the native speakers. One reason for this similarity could be that the learners had high intermediate English proficiency. Other reasons may include the recent opening of the Saudi government to the outer world. Tourism is 
now open to foreigners. Another reason behind this high pragmatic proficiency is the latest introduction of English cinemas in Saudi Arabia, so participants were more likely to listen to natives in authentic real-life situations. However, with this in mind, there were some pragma-linguistic differences between native English speakers and some Saudi learners. Some of the expressions produced by Saudi learners showed a misunderstanding of the expected expression, their answers were long-winded and the used expressions that seemed rude to formal speakers. They also conveyed first language transfer. One limitation of this study was the number of participants. Furthermore, only female participants were investigated because of the difficulties faced in reaching male participants. Future research may explore male participants along with other females at different places in Riyadh and other cities in Saudi Arabia. EFL learners from different parts of the world should also be explored to compare the data. Other levels of English proficiency were also assessed.The findings of the current study are of use to linguists, researchers, language instructors, and students. It provides them with an empirical clear vision of the status of conventional expressions among Saudi female EFL learners. It also calls for further investigation of conventional EFL expressions locally and globally. It also demands curriculum development at all English proficiency levels to overcome such pragma-linguistic issues and improve learners' verbal communication by introducing more authentic materials in curricula. It also highlights the pragma-linguistic features of EFL speakers.

Funding: This research was funded by the Deanship of Scientific Research at Princess Nourah bint Abdulrahman University through the Fast-Track Research Funding Program.

Competing Interests: The author declares that there are no conflicts of interests regarding the publication of this paper.

\section{REFERENCES}

Al-Kahtani, S. A. W. (2005). Refusals realizations in three different cultures: A speech act theoretically-based cross-cultural study. Journal of King Saud University, 18(1), 35-37.

Bardovi-Harlig, K. (2009). Conventional expressions as a pragmalinguistic resource: Recognition and production of conventional expressions in L2 pragmatics. Language Learning, 59(4), 755-795. Available at: https://doi.org/10.1111/j.14679922.2009.00525.x.

Bardovi-Harlig, K., \& Vellenga, H. E. (2012). The effect of instruction on conventional expressions in L2 pragmatics. System, 4O(1), 77-89. Available at: https://doi.org/10.1016/j.system.2012.01.004.

Boers, F., \& Lindstromberg, S. (2009). Optimizing a Lexical Approach to Instructed second language acquisition (pp. 1). Basingstoke, UK: Palgrave Macmillan.

Cedar, P. (2017). Apology strategies used by EFL undergraduate students in Indonesia. International Journal of Applied Linguistics and English Literature, 6(6), 214-222. Available at: http://dx.doi.org/10.7575/aiac.ijalel.v.6n.6p.214.

Chen, C.-F. E. (2006). The development of e-mail literacy: From writing to peers to writing to authority figures. Language Learning E Technology, $10(2), 35-55$.

Coulmas, F. (1981). Conversational routine: Explorations in standardized communication situations and prepatterned speech. The Hague: Mouton.

DeBoer, A. J. (2015). Second language learners' recognition and production of conventional expressions: The role of proficiency, length of stay, and intensity of interaction. Culminating Projects in English. Minnesota, MI: St. Cloud State University. The Respository at St. Cloud State.

Edmonds, A. (2014). Conventional expressions: Investigating pragmatics and processing. Studies in Second Language Acquisition, 36(1), 69-99. Available at: https://doi.org/10.1017/s0272263113000557.

Edmondson, W., \& House, J. (1991). Do learners talk too much? The waffle phenomenon in interlanguage pragmatics. In Phillipson R., E. Kellerman, L Selinker, M. Smith \& M. Swain (Eds.), Foreign/Second language pedagogy research: A commemorative volume for Claus Faerch (pp. 273-287). Clevedon: Multilingual Matters.

Ellis, R. (2008). The study of second language acquisition (2nd ed.). Oxford: Oxford University Press. 
Fairchild, S., Mathis, A., \& Papafragou, A. (2020). Pragmatics and social meaning: Understanding under-informativeness in native and non-native speakers. Cognition, 200, 104171. Available at: https://doi.org/10.1016/j.cognition.2019.104171.

Félix-Brasdefer, J. C. (2003). Declining an invitation: A cross-cultural study of pragmatic strategies in American English and Latin American Spanish. Multilingua, 22(3), 225-255. Available at: https://doi.org/10.1515/mult.2003.012.

Garcia, P. (2004). Developmental differences in speech act recognition: A pragmatic awareness study. Language Awareness, 13(2), 96-115. Available at: https://doi.org/10.1080/09658410408667089.

Geeslin, K., \& Gudmestad, A. (2010). An exploration of the range and frequency of occurrence of forms in potentially variable structures in second-language Spanish. Studies in Second Language Acquisition, 32(3), 433-463.

Grice, H. P. (1975). Logic and conversation. In P. Cole, \& J. L. Morgan. (Eds.), Syntax and Semantics, Speech Acts (Vol. 3, pp. 41-58). New York: Academic Press.

Gu, X. (2011). The effect of explicit and implicit instructions of request strategies. Intercultural Communication Studies, 20(1), 104123.

House, J. (1996). Developing pragmatic fluency in English as a foreign language: Routines and metapragmatic awareness. Studies in Second Language Acquisition, 18(2), 225-252. Available at: https://doi.org/10.1017/s0272263100014893.

Kasper, G., \& Schmidt, R. (1996). Developmental issues in interlanguage pragmatics. Studies in Second Language Acquisition, 18(2), 149-169. Available at: https://doi.org/10.1017/s0272263100014868.

Mukhallafi, T. R. (2019). English in Saudi Arabia: Status and challenges in the light of Prince Mohammad Bin Salman's Vision 2030. International Journal of English Linguistics, 9(4), 209. Available at: https://doi.org/10.5539/ijel.v9n4p209.

Nattinger, J. R., \& DeCarrico, J. S. (1992). Lexical phrases and language teaching. Oxford: Oxford University Press.

Park, Y. (2016). Pragma-linguistic differences in Korean EFL student productions of conventional expressions. English Teaching, $71(4), 3-26$.

Pawley, A., \& Syder, F. (1983). Two puzzles for linguistic theory: Native-like selection and native-like fluency. In Richards. J. C. and Schmidt. R. W. (Eds.), Language and Communication (pp. 191-225). London: Longman.

Schmitt, N., \& Carter, R. (2004). Formulaic sequences in action. In Schmitt. N. (Ed.), Formulaic sequences: Acquisition, processing, and use (pp. 1-22). Amsterdam: Benjamins.

Taguchi, N. (2007). Development of speed and accuracy in pragmatic comprehension in English as a foreign language. Tesol Quarterly, 41(2), 313-338. Available at: https://doi.org/10.1002/j.1545-7249.2007.tb00061.x.

Taguchi, N. (2008). Cognition, language contact, and the development of pragmatic comprehension in a study-abroad context. Language Learning, 58(1), 33-71. Available at: https://doi.org/10.1111/j.1467-9922.2007.00434.x.

Tateyama, S. (2001). The role of input enhancement in developing pragmatic competence. In K. Rose \& G. Kasper (Eds.), Pragmatics in language teaching (pp. 200-222). Cambridge: Cambridge University Press.

Wray, A. (1999). Formulaic language in learners and native speakers. Language Teaching, 32(4), 213-231. Available at: https://doi.org/10.1017/s0261444800014154.

Wray, A., \& Perkins, M. (2000). The functions of formulaic language: An integrated model-the vocabulary-management profile. Language \& Communication, 20(1), 1-28.

Wujiabudula, A. (2018). An investigation on second language learners' production of conventional expressions in L2 pragmatics. Advances in Language and Literary Studies, 9(5), 43-48.

Yusuf, N. A., \& Huda. (2016). Beyond oil - the transformation to a market-based approach: Envision Saudi Arabia 2030. Journal of Economics and Sustainable Development, 7(14), 20 - 24.

Views and opinions expressed in this article are the views and opinions of the author(s), International Journal of English Language and Literature Studies shall not be responsible or answerable for any loss, damage or liability etc. caused in relation to/arising out of the use of the content. 